\title{
Why did the United States Evolve from the Largest International Creditor in 1980 to the Largest International Debtor in 1990?
}

\author{
Robert Aliber ${ }^{1}$
}

Accepted: 17 December 2020/ Published online: 31 January 2021

(C) The Author(s) 2021

\begin{abstract}
Remarkable transformation of the U.S. international investment position occurred over the last 40 years. U.S. net foreign assets were larger than combined net foreign assets of all other creditors. By 1990, foreign-owned U.S. securities and real assets were larger than U.S. owned foreign securities and assets. This change occurred without the U.S. Treasury borrowing in foreign currency and few U.S. firms borrowing, reflecting a surge in foreign purchases of U.S. securities. Inferences from the currency composition of portfolio changes of those who acquired U.S. dollar securities suggest that foreign savers took the initiative on cross-border investment inflows. The U.S. could not have developed a larger capital account surplus after 1980 unless a similar increase in the U.S. current account deficit occurred. The primary factor that led to the U.S. current account deficit increase was the surge in U.S. stocks and other asset prices, resulting in a U.S. household wealth surge and consumption boom. The foreign saving inflow displaced domestic saving. In addition, an increase in the price of the U.S. dollar led to expenditure-switching from U.S. goods to increasingly less expensive foreign goods. When investor demand for U.S. dollar securities declined, the U.S. dollar price fell in 1992, 2002, and 2020 and the price of U.S. dollar securities declined. The paper discusses the source of the change in the U.S. international investment position, the flow of foreign saving to the U.S., cyclical variability in the foreign saving flow to the U.S., and the potential impact of an adjustable parity arrangement.
\end{abstract}

Keywords International investment $\cdot$ Capital flows $\cdot$ Adjustable parity $\cdot$ Foreign saving $\cdot$ Crowding out

JEL $\quad \mathrm{F} 33 \cdot \mathrm{G} 01 \cdot \mathrm{G} 15 \cdot \mathrm{G} 33$

Robert Aliber

robert.aliber@gmail.com

1 University of Chicago, Chicago, USA 


\section{Introduction}

In 1980, the United States (U.S.) net international creditor position was larger than the combined net creditor positions of all other countries. By 1990, foreign-owned U.S. dollar securities and real assets were larger than U.S.-owned foreign assets. This dramatic change in the U.S. international investment position occurred even though the U.S. Treasury had not borrowed in a foreign currency and few U.S. firms had sold their debts to foreign lenders to obtain the money to finance their U.S. activities. Instead, the change in the U.S. international investment position resulted from the surge in foreign purchases of U.S. dollar securities.

The first dramatic reversal in the U.S. international investment position was during World War I when the U.S. morphed from an international debtor to an international creditor. The U.S. had become an international debtor at birth in 1789, since non-residents owned some of the physical assets in the then 13 states. Moreover, the revolutionary government had borrowed \$5 million from the French government in 1778. U.S. international indebtedness increased throughout the nineteenth century as state governments and the railroads sold their debts in London and other foreign centers. In 1910, U.S. international indebtedness was less than one percent of U.S. gross domestic product (GDP). During the First World War, British and other European demand for U.S. foodstuffs and munitions increased. Initially these purchases were financed with money from selling U.S. securities acquired in the nineteenth century and then from selling debts to American investors and the U.S. government. The U.S. international creditor position increased modestly over the next 70 years as a small part of U.S. saving was used to purchase foreign securities and real assets.

The sharp increase in foreign demand for U.S. dollar securities in the 1980s might have resulted from shocks in Japan, Germany, and other foreign countries that led to declines in investment spending and increases in excess saving. Alternatively, the shock might have originated in the U.S., which could have experienced an increase in U.S. investment spending (or an increase in the U.S. fiscal deficit) relative to U.S. domestic saving. The increase in the U.S. trade deficit and the counterpart re-configuration of trade imbalances reflect changes in the saving-investment relationship. The U.S. had a trade deficit during most of the 100 years when its net debtor position was increasing. Did the change in the configuration of the U.S. and foreign trade balances in the 1980s reflect that the U.S. demand for saving had become larger than U.S. investment, or instead did the increase in the foreign demand for U.S. dollar securities displace U.S. saving?

The reversal in the U.S. international investment position occurred soon after the transition from the International Monetary Fund (IMF) arrangement of adjustable parities to the floating currency arrangement. The IMF arrangement had been designed to limit changes in the prices of currencies and the size of each country's current account deficit or surplus. There are no such limits under the floating rate arrangement. It seems unlikely that the changes in the rules for exchange market intervention by central banks and adoption of the floating currency arrangement would have had a significant impact on saving and 
investment in individual countries. New rules might have been adopted to limit changes in the market price of the U.S. dollar and the real price projected from differences in national inflation rates.

There have been four episodes since 1980 when the U.S. capital account surplus increased. One occurred in each of the four decades: 1980s, 1990s, 2000s, and 2010s. These changes in the U.S. capital account surplus in each decade can be identified as a dollar cycle. Each cycle had an expansive phase when the U.S. capital account surplus increased and a contractive phase when this surplus declined. The price of U.S. securities increased in the expansive phase of each of the four cycles. The price of the U.S. dollar increased in the expansive phase of the first, second, and fourth cycle. A recession followed the end of each of the contractive phases.

The first question that is addressed is whether the shock that led to the large change in the U.S. international investment position in the 1980s originated in the U.S. because the U.S. had too little saving or in Japan and other countries that had excess saving. Several of my earlier works (e.g., Aliber 2018) referred to the crowding-out versus crowding-in distinction. Did American borrowers crowd out foreign borrowers by paying higher interest rates than some displaced foreign borrowers would have paid? Alternatively, did the foreign savers crowd into the U.S. market and displace American savers by accepting lower interest rates than some American savers would have accepted?

The second question pertains to adjustments in the U.S. economy that occurred to ensure that there would be an increase in the U.S. current account deficit that would correspond to the autonomous increase in the U.S. capital account surplus. Otherwise, the market in the U.S. dollar would not have cleared. The transfer problem process was at work in the U.S. as in Iceland. U.S. domestic demand had to expand to absorb the real resources that were the counterpart of the financial transfer to the U.S. The principal factor that led to the increase in U.S. household and business demand was the surge in household wealth.

The third question is why openness of the U.S. economy to the inflow of foreign saving led to a secular decline in the competitiveness of firms that produce in the U.S., as is evident in the increase in the average annual U.S. trade deficit as a ratio of U.S. GDP from each successive decade since 1980. The increase in the U.S. capital account surplus led to a higher price for the U.S. dollar and hence to a decline in the competitiveness of firms producing in the U.S. The U.S. industrial economy was hollowed out as some industrial capacity was scrapped. As U.S. manufacturing capacity declined, the price of the U.S. dollar would tend to be lower for each level of foreign investment in the U.S.

The fourth question, one in counterfactual history, is whether the U.S. would have morphed into the world's largest debtor if the adjustable parity arrangement had been retained. Once one is in the realm of counterfactual history, a multitude of different assumptions can be made. The U.S. became a major international debtor because market forces led to sharp undervaluation of the currencies of the major U.S. trading partners. If the rules for currency market intervention had required that countries limit the undervaluation of their currencies, then the U.S. international debtor position would have increased at a less rapid rate. 


\section{Crowding-Out Versus Crowding-In}

The crowding-out versus crowding-in distinction is centered on whether American borrowers or non-American savers take the initiative in cross-border investment inflows to the U.S. The answer is embedded in the data on the currency of denomination of U.S. exports of securities. If American borrowers take the initiative, then they are likely to denominate the securities in the savers' currencies to reduce their interest costs. The inference from the lack of price quotes for securities denominated in a foreign currency issued by U.S. borrowers is that foreign investors bought off-the-shelf U.S. dollar securities. There is no evidence that U.S. borrowers took the initiative to denominate their securities in a foreign currency so that these securities would be more attractive to foreign savers. (Some U.S. state governments provided subsidies to foreign multinational firms to induce them to establish subsidiaries within their jurisdictions.)

A second marker for whether foreign investors or American borrowers have taken the initiative with respect to the increase in the U.S. capital account surplus is whether the price of the U.S. dollar was high or low at the time that the U.S. capital account surplus increased. If the price of the U.S. dollar was high, the inference is that foreign savers took the initiative. The data show that the price of the U.S. dollar increased as the U.S. capital account surplus increased.

A third marker is the change in the price of U.S. dollar securities as the U.S. capital account surplus increases. If the price of U.S. securities increases during a U.S. capital account surplus increase, the inference is that foreign savers have taken the initiative to buy more U.S. dollar securities.

The twin deficits explanation is that the U.S. tax reductions in 1981 and 1982 led to a larger U.S. fiscal deficit. The story is that interest rates on U.S. dollar securities were higher, which in turn led to a larger foreign demand for these securities, higher prices for the U.S. dollar, and larger U.S. trade deficits. In fact, interest rates on U.S. dollar securities declined despite the increase in the U.S. fiscal deficit, which apparently reflected the decline in the anticipated U.S. inflation rate. The increase in foreign purchases of U.S. dollar securities in the first half of the 1980s was many times larger than the increase in the U.S. fiscal deficit.

\section{U.S. Domestic Adjustments in the Four U.S. Dollar Cycles}

The balance of payments accounting convention is that the U.S. could not experience an increase in its capital account surplus unless there was a counterpart increase in the U.S. current account deficit. The primary factor that led to the increase in the U.S. current account deficit was the increase in U.S. household wealth that followed from the higher prices of U.S. dollar securities. The second factor was the higher price of the U.S. dollar, which led to expenditure-switching and larger purchases of foreign goods because they had become less expensive relative to U.S. produced goods. 
The supply of goods available to Americans increased as the U.S. capital account surplus increased. These goods had to be absorbed, which occurred because of the U.S. consumption boom, whose mirror was the decline in U.S. household saving. Thus, the increase in the inflow of foreign saving to the U.S. during the expansive phase of each of these four cycles displaced, rather than supplemented, U.S. domestic saving. The U.S. economy was jerked around by the sharp variability in the U.S. capital account surplus. An increase in this surplus led to higher prices for U.S. securities and a consumption boom, while a decline in the surplus led to lower prices for these securities. As the U.S. capital account surplus increased, the price of U.S. stocks and other assets generally increased. The increase in the prices of U.S. securities was a transient phenomenon as long as the U.S. capital account surplus increased.

The consumption booms in the U.S. during each of these four cycles challenges the view that foreign saving flowed to the U.S. to supplement U.S. saving. If there had been a shortage of saving, U.S. asset prices would not have increased (Bergsten and Gagnon, 2012). In fact, there was a global excess supply of saving, and much of it was absorbed through the consumption booms in the U.S. The excess supply of saving was a cyclical phenomenon. The surge in U.S. consumption spending as an integral part of the adjustment process means that the inflow of foreign saving displaced domestic saving. The surge in domestic consumption spending implies that the initiative for cross-border investment flow is with foreign savers.

\section{Long-Run Decline in U.S. Competitiveness}

The ratio of the annual U.S. trade deficit to U.S. GDP increased in each of the four decades since 1980 by about one percentage point per decade. The paradox is that the firms producing in the U.S. seem less competitive despite the real decline in the price of the U.S. dollar. This decline was not large enough to prevent development of an increasingly large U.S. trade deficit.

As the price of the U.S. dollar increased in the first half of the 1980s, the U.S. industrial economy was hollowed out. The U.S. price of foreign goods declined below the price of comparable goods produced in the U.S. and U.S. firms scrapped some U.S. goods-producing capacity. Scrapping occurred at the same time as the U.S. domestic demand and U.S. trade deficit surged. When the U.S. capital account surplus declined, the price of the U.S. dollar and U.S. trade deficit declined (MacDonald 2000).

Scrapping some industrial capacity means that the effective price of the U.S. dollar would need to decline if the U.S. trade deficit were to remain unchanged. (An analogy: An oil-exporting country experiences a loss of production and exports. As some of its oil wells become less productive, the effective price of its currency declines.) When the U.S. capital account surplus began to decline, the price of the U.S. dollar also fell. Domestic investment increased but by less than the amount of capacity that had been scrapped. In essence, there is a ratchet effect, as the price of the U.S. dollar would be lower for each value of the U.S. trade balance. 


\section{Conclusion}

The U.S. international investment position morphed from a debtor to a creditor during the First World War as Great Britain and other European nations sold some of their U.S. dollar securities and borrowed in the U.S. to obtain the money to buy munitions and foodstuffs. In the 1980s, the U.S. international investment position morphed from the world's largest creditor to the largest debtor even though the U.S. Treasury did not borrow in a foreign currency and few U.S. firms sold their debts in foreign centers to get the funds to finance their U.S. activities. The dramatic change in the U.S. international investment position came about because of the cyclical surges in foreign purchases of U.S. dollar securities and real assets, which led to increases in the price of the U.S. dollar and increases in the U.S. trade deficit (Gray 2004).

The first question addressed in this paper was whether the initiative toward an increase in cross-border investment flows to the U.S. was taken by investors resident in foreign countries that were seeking higher return than those available in their domestic markets, or was instead taken by U.S. borrowers that were seeking to reduce their costs of finance (Klein and Pettis, 2020). Nearly all of the increase in investment flows to the U.S. reflected initiatives by foreign investors to buy off-the-shelf U.S. dollar securities.

The usual inference from the increase in the flow of saving to the U.S. is that Americans save too little. The U.S. could not develop a capital account surplus unless there was a counterpart increase in the U.S. current account deficit. The primary factor that contributed to the U.S. current account deficit was the sharp increase in the price of U.S. stocks and as a result in U.S. household wealth, which led to a consumption boom. U.S. spending on both domestic and foreign goods increased sharply. The secondary factor was the increase in the price of the U.S. dollar, which led to an increase in spending on foreign goods. When the foreign demand for U.S. dollar securities declined, the price of U.S. securities fell and the price of the U.S. dollar declined. The increase in the inflow of foreign saving displaced domestic saving and facilitated a surge in U.S. consumption spending. If the inflow of foreign saving was an adjustment to compensate for the shortage of domestic saving, the U.S. would not have experienced surges in asset prices in each decade since 1980.

The increase in cross-border investment flows to the U.S. led to an increase in the price of the U.S. dollar and an increase in the U.S. trade surplus. Some U.S. industrial capacity was idled and some was scrapped. When the cross-border investment inflows to the U.S. slowed, the price of the U.S. dollar declined and some of the idled U.S. capacity was likely returned to production. If the price of the U.S. dollar returns to its pre-shock level, the price of the U.S. dollar may be lower because U.S. productive capacity is smaller.

Much of the cyclical variability in the U.S. capital account surplus resulted from the leads and lags response of investors to changes in the relationship between interest rates on U.S. dollar securities and on comparable securities denominated in the other major currencies, adjusted for the anticipated increase 
in the price of the U.S. dollar. The value of the anticipated change in the price of the U.S. dollar and changes in this anticipated value are likely to be greater if currencies are not attached to parities, in part for the obvious reason that central banks are not committed to limiting the range of movement in the price of currencies. In addition, changes in the price of the U.S. dollar that occur in response to changes in the leads and lags induce other investors to buy more dollar securities.

It was not inevitable that the move away from the IMF arrangement of adjustable parities would cause a large increase in U.S. international indebtedness. The postadjustable parity arrangement could have had a provision that would have limited the undervaluation of individual currencies and the trade surpluses of participating countries to three or five percent of their respective GDP. The U.S. evolved from the largest international creditor to the largest international debtor in 1980 because the major U.S. trading partners had developed massive excess investment and there were no rules or conventions that limited the undervaluation of their currencies.

Open Access This article is licensed under a Creative Commons Attribution 4.0 International License, which permits use, sharing, adaptation, distribution and reproduction in any medium or format, as long as you give appropriate credit to the original author(s) and the source, provide a link to the Creative Commons licence, and indicate if changes were made. The images or other third party material in this article are included in the article's Creative Commons licence, unless indicated otherwise in a credit line to the material. If material is not included in the article's Creative Commons licence and your intended use is not permitted by statutory regulation or exceeds the permitted use, you will need to obtain permission directly from the copyright holder. To view a copy of this licence, visit http://creativecommons.org/ licenses/by/4.0/.

\section{References}

Aliber, R. Z. (2018). The $\$ 600$ billion increase in the U.S. trade deficit since 1980 has led to the loss of three million U.S. manufacturing jobs, Capitalism and Society, 13(2): Article 4. Available at: https:// papers.ssrn.com/sol3/papers.cfm?abstract_id=3304816

Bergsten, C.F. \& Gagnon, J. E. (2012). Currency Manipulation, the US Economy, and Global Economic Order, Policy Brief, Peterson Institute for International Economics. Available at: https://www.piie. com/publications/policy-briefs/currency-manipulation-us-economy-and-global-economic-order

Gray, H. P. (2004). The Exhaustion of the Dollar: Its Implications for Global Prosperity. Basingstoke: Palgrave Macmillan.

Klein, M. C. \& Pettis, M. (2020). Trade wars are class wars: How rising inequality distorts the global economy and threatens international stability, New Haven: Yale University Press.

MacDonald, R. (2000). Concepts to Calculate Equilibrium Exchange Rates: An Overview, Deutsche Bundesbank Discussion Paper Series 1, No. 2000,03. Available at: https://www.econstor.eu/ bitstream/10419/19531/1/200003dkp.pdf

Publisher's Note Springer Nature remains neutral with regard to jurisdictional claims in published maps and institutional affiliations. 